\title{
Amylose content in rice (Oryza sativa) affects performance, glycemic and lipidic metabolism in rats
}

\author{
Teor de amilose do arroz (Oryza sativa) afeta o desempenho, metabolismo glicêmico e lipídico em ratos
}

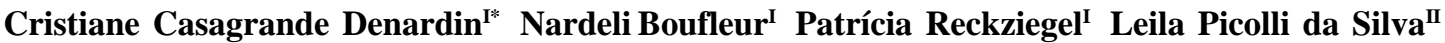 \\ Melissa Walter III
}

\begin{abstract}
This research aimed at evaluating the effect of diets with high, intermediate and low amylose content of rice on performance, glycemic and lipidic metabolism in rats. Male Wistar rats were fed diets with grains of cooked rice of the cultivars 'IRGA 417', 'IRGA 416' and 'MOCHI' with high, intermediate and low amylose content, respectively. Wet and dry fecal production and serum HDL cholesterol were not affected by amylose content. The animals in the treatments with high amylose content ('IRGA 417') presented lower feed intake, body weight gain and apparent digestibility, higher fecal water content and nitrogen excretion, reduced fecal $\mathrm{pH}$, lower postprandial blood glucose response, serum total cholesterol and triglycerides levels and pancreas weight, and higher fasting serum glucose concentration and liver weight. Amylose:amylopectin ratio significantly affects rice starch digestion in the gastrointestinal tract, affecting some biologically relevant parameters.
\end{abstract}

Key words: rice grains, hyperglycemia, metabolic responses, rats.

\section{RESUMO}

O objetivo deste trabalho foi avaliar o efeito de dietas com alto, intermediário e baixo teor de amilose sobre o desempenho, metabolismo glicêmico e lipídico em ratos. Foram utilizados ratos machos Wistar alimentados com rações experimentais elaboradas com grãos de arroz cozido das cultivares 'IRGA 417', 'IRGA 416' e 'MOCHI' com alto, intermediário e baixo teores de amilose, respectivamente. A produção de fezes úmidas e secas e colesterol HDL não foram afetados pelo teor de amilose dos grãos. Os animais submetidos ao tratamento com alto teor de amilose (IRGA 417) apresentaram menores consumo, ganho de peso $e$ digestibilidade aparente, maiores umidade nas fezes $e$ excreção de nitrogênio, reduzido pH fecal, concentração plasmática posprandial de glicose, colesterol total, triglicerídeos e peso do pâncreas e maior concentração de glicose no jejum e peso do fígado. A proporção amilose e amilopectina nos grãos afeta significativamente a digestão do amido de arroz no trato gastrointestinal, afetando alguns parâmetros biologicamente relevantes.

Palavras-chave: grãos de arroz, hiperglicemia, resposta metabólica, ratos.

\section{INTRODUCTION}

Rice (Oryza sativa) is consumed by $2 / 3$ of world population and at least for half of them (including many countries in Latin America, Asia and the Pacific islands) it is the main source of energy in the diet (HU et al., 2004). This popularity is especially due to rice being a low cost food, of easy and quick preparation, and versatile matching different dishes. This cereal is mainly composed of carbohydrates, which are present mostly as starch (90\%) in the endosperm (COFFMAN \& JULIANO, 1987), with varying amounts in the grain due to genetic and environmental factors. Additionally, the rate and extension of starch digestion can be influenced by different factors, including the variation in

INúcleo Integrado de Desenvolvimento em Análises Laboratoriais (NIDAL), Departamento de Tecnologia e Ciência de Alimentos (DTCA), Centro de Ciências Rurais (CCR), Universidade Federal de Santa Maria (UFSM), 97105-900, Santa Maria, RS, Brasil. Email: cristiane_denardin@yahoo.com.br. *Autor para correspondência.

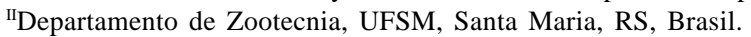

IIIDepartamento de Fitotecnia, UFSM, Santa Maria, RS, Brasil. 
the amylose:amylopectin ratio, grain processing (especially parboiling), physicochemical properties (particularly gelatinization characteristics), particle size and the presence of lipid-amylose complexes (HU et al., 2004).

The main differences in starch composition that influence physicochemical and metabolic properties of rice are caused by the variation in the ratio of its two macromolecules, amylose and amylopectin. Amylose is essentially a linear molecule in which D-glucose units are linked by a-1.4 glucosidic bonds, while amylopectin, a branched polymer, contains both a-1.4 and a-1.6 bonds. Researches by FREI et al. (2003) report great variations in the amylose:amylopectin ratio in rice grains of different varieties that allow their classification as waxy (1-2\% amylose), very low amylose content (2$12 \%)$, low amylose content (12-20\%), intermediate amylose content (20-25\%) and high amylose content (25-33\%) (COFFMAN \& JULIANO, 1987). Considering the metabolic effects, FREI et al. (2003) report that starchy foods with high amylose levels are associated with lower blood glucose levels and slower emptying of the human gastrointestinal tract compared to those with low levels of this macromolecule. These conditions are relevant, especially in the formulation of diets for diabetics, because the slower digestion and absorption of carbohydrates help to maintain regular levels of glucose in the blood and to reduce insulin response, probably due to increased time of intestinal transit (BEHALL et al., 1988). This variation, associated with food processing, can result in different glycemic and insulinemic responses, and hormonal profiles (GODDARD et al., 1984).

Therefore, considering these aspects, the fact that the preferences of the Brazilian population for rice's eating quality vary according to the region, and that this is related to amylose:amylopectin ratio in the grains of different cultivars, this research aimed at evaluating the effect of diets with Brazilian cultivated rice grains with high, intermediate and low amylose content on performance, glycemic and lipidic metabolism in rats.

\section{MATERIALS AND METHODS}

Three diets were formulated according to the recommendation of the American Institute of Nutrition (AIN) (REEVES et al., 1993), by whole substitution of corn starch, and by partial substitution of casein, soybean oil and fiber for grains of cooked rice of the cultivars 'IRGA 417', 'IRGA 416' and Mochi, obtained from the Rice Experimental Station of IRGA (Cachoeirinha/RS), in the year of 2004. The rice grains were traditionally cooked $(1: 2 \mathrm{w} / \mathrm{v})$, hot-air dried at $50^{\circ} \mathrm{C}$, grounded and immediately to make use of produce the diets. These three diets formed the treatments; 'IRGA 417': diets formulated with cooked rice grains of the cultivar 'IRGA 417', with $22.95 \%$ of amylose; 'IRGA 416': diet formulated with cooked rice grains of the cultivar 'IRGA 416', with $17.42 \%$ of amylose; MOCHI: diet formulated with cooked rice grains of the cultivar 'Mochi', with 2.92\% of amylose.

The Ethics and Care Committee for Laboratory Animals of Federal University of Santa Maria (UFSM) agreed with the study protocol (23081.004118/2007-34). Twenty-four male Wistar (F1) rats (Rattus norvegicus albino) (59.2 $\pm 5.2 \mathrm{~g}$; aged: 21 days) were obtained from "Biotério Central” of UFSM and were randomly distributed among the treatments (8 animals/treatment), being individually housed in metabolic cages, with free access to feed and water. The period of adaptation to the experimental diets was 5 days. After that, the experimental period (25 days) began, when the determination of feed intake and the collection of feces were made daily. The body weight of the animals was recorded every three days. These data and samples were collected to determine feed intake, body weight gain, apparent dry matter digestibility, wet and dry fecal production, fecal water content, fecal $\mathrm{pH}$ and fecal nitrogen excretion.

After the fifth day of adaptation, the animals were randomly selected, every other day, in groups of 6 (two animals/treatment) for the analysis of the postprandial blood glucose response and these animals were then excluded from the next selections. After a $12 \mathrm{hr}$-overnight fast, the animals were fed $2 \mathrm{~g}$ of one of the test diets, which was totally consumed in a period of $20 \mathrm{~min}$. Blood samples of tail vein were taken at fasting (before the consumption of the meal) and 15, 30, 45, 60, 90 and 150 minutes after the meal to measure serum glucose levels, which were determined using Accu-Chek Active ${ }^{\circledR}$ (Roche - São Paulo - Brazil) monitoring kit. After the analysis of the postprandial blood glucose response of all the animals, there was a period of two days for the animals to recover from the stress caused by fasting and handling, and then the experimental period was started.

On the last experimental day, after a $12 \mathrm{~h}$ overnight fast, the animals were weighed, anesthetized and killed by cardiac puncture, and blood was collected for the quantification of serum glucose, total cholesterol, HDL cholesterol and triglycerides. The liver and pancreas were immediately removed and weighed for the determination of their weight (as g $100 \mathrm{~g}^{-1}$ of animal weight). During the adaptation and experimental period, temperature was maintained at $21 \pm 1^{\circ} \mathrm{C}$, and lighting was controlled by alternating periods of $12 \mathrm{~h}$ of light and dark.

Ciência Rural, v.42, n.2, fev, 2012. 
The amylose value was determined according to the iodimetric technique (Blue Value), described by GILBERT \& SPRAGG (1964). The determinations of fecal water content $\left(105^{\circ} \mathrm{C} / 12 \mathrm{~h}\right)$ and fecal nitrogen content (Micro-Kjeldahl) were carried out according to methods mentioned in Association of Official Analytical Chemists (AOAC, 1998). Fecal pH was obtained from a solution of $1 \mathrm{~g}$ of partly dried feces $\left(60^{\circ} \mathrm{C} / 48 \mathrm{~h}\right)$ in $10 \mathrm{ml}$ of distilled water. Apparent dry matter digestibility (AD) was calculated as the proportion of food ingested that was not later recovered in the feces. Serum glucose, total cholesterol, HDL cholesterol and triglycerides in the blood were determined with the kits Glucox 500, Enzymatic Cholesterol 250, HDL Cholesterol and Enzymatic Triglycerides Liquid, respectively, from Doles $^{\circledR}$ (Goiânia, Goiás, Brazil).

The experiment was carried out in a completely random design. The results obtained were submitted to analysis of variance (ANOVA), with the means compared by Duncan's test at $5 \%$ of significance. All results were expressed as the mean value \pm standard error (SE). Statistical analyses were performed using SPSS for Windows 8.0.

\section{RESULTS AND DISCUSSION}

Body weight gain of the animals was significantly higher in the MOCHI (low amylose content) and IRGA 416 (intermediate amylose) treatments than in the treatment with high amylose content (IRGA 417). Mean food intake in the MOCHI treatment was significantly greater than in the other two treatments (Table 1).

The majority of researches carried out with rats and humans report no effect of amylose content on consumption and body weight gain (GODDARD et al., 1984; KABIR et al., 1998). However, ZHOU \& KAPLAN (1997), evaluating the digestibility of two starch sources, potato with 70-75\% amylopectin and maize with $70 \%$ amylose, in an experiment with rats during four weeks, also observed significantly greater feed intake with the high amylopectin diet, although no effect was seen on body weight gain. Usually rice grains with low amylose content are more palatable (RAMIREZ, 1991), which can explain the higher feed intake that, associated with the higher digestibility of amylopectin, influenced the body weight gain of the animals. This hypothesis is supported by the research carried out by SCLAFANI et al. (1987) with rats, which demonstrated that the animals have receptors that discriminate between the tastes of carbohydrates like starch, what leads to the preference of consuming branched-chain starch (amylopectin) rather than unbranched starch (amylose).

Apparent dry matter digestibility (AD) was significantly higher in the treatments with intermediate (IRGA 416) and low (MOCHI) amylose content (Table 1). Digestibility studies based on the analysis of starch

Table 1 - Effect of different amylose:amylopectin ratios on body weight gain, apparent dry matter digestibility (AD), daily feed intake, wet (WFP) and dry (DFP) fecal production, fecal water content (FWC), fecal pH, nitrogen excretion (NF), fasting serum glucose, total cholesterol, HDL cholesterol and triglycerides (mg/dl); and the weight of the liver and pancreas (g $100 \mathrm{~g}^{-1}$ of animal weight) of the animals ${ }^{1}$.

\begin{tabular}{|c|c|c|c|}
\hline Variable & IRGA 417 & IRGA 416 & MOCHI \\
\hline Body weight gain $\left(\right.$ g day $^{-1}$ ) & $105.68 \pm 7.20^{\mathrm{b}}$ & $115.88 \pm 2.90^{\mathrm{a}}$ & $115.35 \pm 5.26^{\mathrm{a}}$ \\
\hline $\mathrm{AD}(\%)$ & $94.13 \pm 0.45^{\mathrm{b}}$ & $94.66 \pm 0.47^{\mathrm{a}}$ & $94.63 \pm 0.36^{\mathrm{a}}$ \\
\hline Feed intake (g day ${ }^{-1}$ ) & $17.80 \pm 0.40^{\mathrm{b}}$ & $17.57 \pm 0.90^{\mathrm{b}}$ & $18.73 \pm 0.37^{\mathrm{a}}$ \\
\hline WFP $\left(\right.$ g day $\left.^{-1}\right)$ & $1.58 \pm 0.08^{\mathrm{NS}}$ & $1.48 \pm 0.22^{\mathrm{NS}}$ & $1.42 \pm 0.14^{\mathrm{NS}}$ \\
\hline DFP $\left(\right.$ g day $\left.^{-1}\right)$ & $0.91 \pm 0.05^{\mathrm{NS}}$ & $0.88 \pm 0.07^{\mathrm{NS}}$ & $0.92 \pm 0.08^{\mathrm{NS}}$ \\
\hline FWC (\%) & $40.77 \pm 2.67^{\mathrm{a}}$ & $33.92 \pm 3.19^{b}$ & $34.16 \pm 2.71^{\mathrm{b}}$ \\
\hline Fecal Ph & $7.00 \pm 0.11^{\mathrm{b}}$ & $7.30 \pm 0.20^{\mathrm{a}}$ & $7.35 \pm 0.07^{\mathrm{a}}$ \\
\hline NF (\%) & $6.34 \pm 0.24^{\mathrm{a}}$ & $6.04 \pm 0.23^{\mathrm{b}}$ & $4.15 \pm 0.08^{\mathrm{c}}$ \\
\hline Glucose & $174.50 \pm 2.96^{\mathrm{a}}$ & $141.34 \pm 1.38^{b}$ & $150.35 \pm 1.30^{\mathrm{b}}$ \\
\hline Triglycerides & $71.57 \pm 1.18^{\mathrm{b}}$ & $77.47 \pm 1.22^{\mathrm{ab}}$ & $87.57 \pm 1.46^{\mathrm{a}}$ \\
\hline Total cholesterol & $63.67 \pm 2.81^{\mathrm{b}}$ & $74.01 \pm 2.03^{\mathrm{a}}$ & $79.06 \pm 2.60^{\mathrm{a}}$ \\
\hline HDL cholesterol & $59.57 \pm 4.06^{\mathrm{NS}}$ & $61.79 \pm 7.94^{\mathrm{NS}}$ & $65.51 \pm 7.38^{\mathrm{NS}}$ \\
\hline Liver & $3.65 \pm 0.25^{\mathrm{a}}$ & $3.53 \pm 0.09^{\mathrm{b}}$ & $3.72 \pm 0.12^{\mathrm{a}}$ \\
\hline Pancreas & $0.42 \pm 0.04^{\mathrm{b}}$ & $0.49 \pm 0.06^{\mathrm{a}}$ & $0.48 \pm 0.03^{\mathrm{a}}$ \\
\hline
\end{tabular}

${ }^{1}$ Results expressed as mean values \pm standard deviation;

Mean values followed by different letter on the same line are significantly different (Duncan's test at a level of $5 \%$ of significance).

Ciência Rural, v.42, n.2, fev, 2012. 
in the feces have demonstrated an almost complete digestion (99.9\%) of starch from cooked and raw waxy and non-waxy rice cultivars in rats and humans (EGGUM et al., 1993). However, due to the fact that the diets were isoproteic, isolipidic and isocaloric, the differences in the digestibility observed in the present study can be explained by the differences in the molecular structure between amylose and amylopectin. Amylose, having an essentially linear and packed chain, is more compact in the granule, which makes the access of digestive enzymes difficult; on the contrary, the amylopectin molecule, having a branched chain, allows greater access of these enzymes. Thus, amylose might not be totally digested by the enzymes in the gastrointestinal tract, being partly excreted in the feces (BEHALL et al., 1988; GODDARD et al., 1984), leading to the lower $\mathrm{AD}$ observed in the treatment with higher amylose content (IRGA 417). Studies of the in vitro starch digestibility of rice cultivars with varying amylose content reinforce this hypothesis, with the cultivars of higher amylose content showing a lower digestibility than those with low amylose content (HU et al., 2004; FREI et al., 2003).

Although wet (WFP) and dry (DFP) fecal production were not affected by amylose content, treatments with intermediate and low amylose content showed significantly lower fecal water content (FWC) (Table 1). The increased fecal water content in the treatment with high amylose (IRGA 417) confirms the lower digestibility of amylose by enzymes in the gastrointestinal tract. Studies have demonstrated that a higher content of slowly digestible and/or indigestible carbohydrates in the large intestine and cecum results in increased microbial activity and excretion, composed by $80 \%$ of water, and may represent a significant percentage of the fecal bulk (CHERBUT et al., 1997), justifying the higher fecal water content of the animals under IRGA 417 treatment. This increase in fecal water content is important to prevent constipation and hemorrhoids, as well as to provide substrate for microbial growth, which increases the production and concentration of potentially protective products while diluting the concentration of potentially toxic compounds (CHERBUT et al., 1997).

The reduction in fecal $\mathrm{pH}$ and the increase in fecal nitrogen excretion also demonstrate the increased microbial activity observed in the treatment with high amylose content (IRGA 417) (Table 1). From the results, it can be hypothesized that the higher the amylose content in the diet, the more substrate available for fermentation, which, when reaching the colon, is fermented by the bacterial flora, resulting in the production of organic acids. Part of these acids is used by the organism, being an important source of energy to the colon, besides being responsible for modulating the immune response and intestinal flora (BROUNS et al., 2002). Early epidemiological studies indicate that some short-chain fatty acids, especially propionate and butyrate, may reduce by $25-30 \%$ the risk of colorectal cancer, helping in the maintenance of intestinal health and reducing risk factors associated with the development of intestinal inflammation (BROUNS et al., 2002). The other part of the produced acids is excreted in the feces, resulting in the lower $\mathrm{pH}$ observed in the treatment with high amylose content (IRGA 417), which is desirable for the maintenance of the intestinal microflora.

The increase in fecal nitrogen excretion is also an indication of increased fermentative activity with higher amylose content (IRGA 417) (Table 1). A similar result was observed by YOUNES et al. (1995) who, adding indigestible starch fractions to the diet of rats, observed significant increase in fecal nitrogen excretion, which is normally associated with considerable development of cecum microflora, since the breakdown of high amounts of carbohydrates increases nitrogen incorporation into bacterial proteins. The nitrogen required for optimal bacterial growth is provided by proteins escaping small intestine breakdown, endogenous proteins (pancreatic and intestinal secretions, sloughed epithelial cells), or blood urea diffusing into digestive contents (YOUNES et al., 1995). Therefore, the increase in fecal nitrogen excretion could correspond to an increased fecal excretion of bacterial proteins and the change of nitrogen excretion from urine to the feces (DEMIGNÉ \& RÉMÉSY, 1982). This change in nitrogen excretion from urine to the feces may help in the management of chronic renal disease (YOUNES et al., 1995).

Although the glycemic response at 15 minutes was similar in all the treatments, the animals in the treatments with intermediate (IRGA 416) and low (MOCHI) amylose contents presented higher postprandial blood glucose responses in the other points of the curve (60min) compared to the animals in the treatment with high amylose content (IRGA 417) (Figure 1). Similar to the results observed in the present work, KABIR et al. (1998), evaluating the effect of amylose content on glycemic response in rats, observed that the consumption of a diet rich in amylose for three weeks reduced the postprandial blood glucose response, glucose incorporation into lipids and epididymal fat pads of the animals. Similarly, GODDARD et al. (1984) and BRAND MILLER et al. (1992), evaluating the effect of increased contents of amylose of rice cultivars on the glycemic response in humans, 


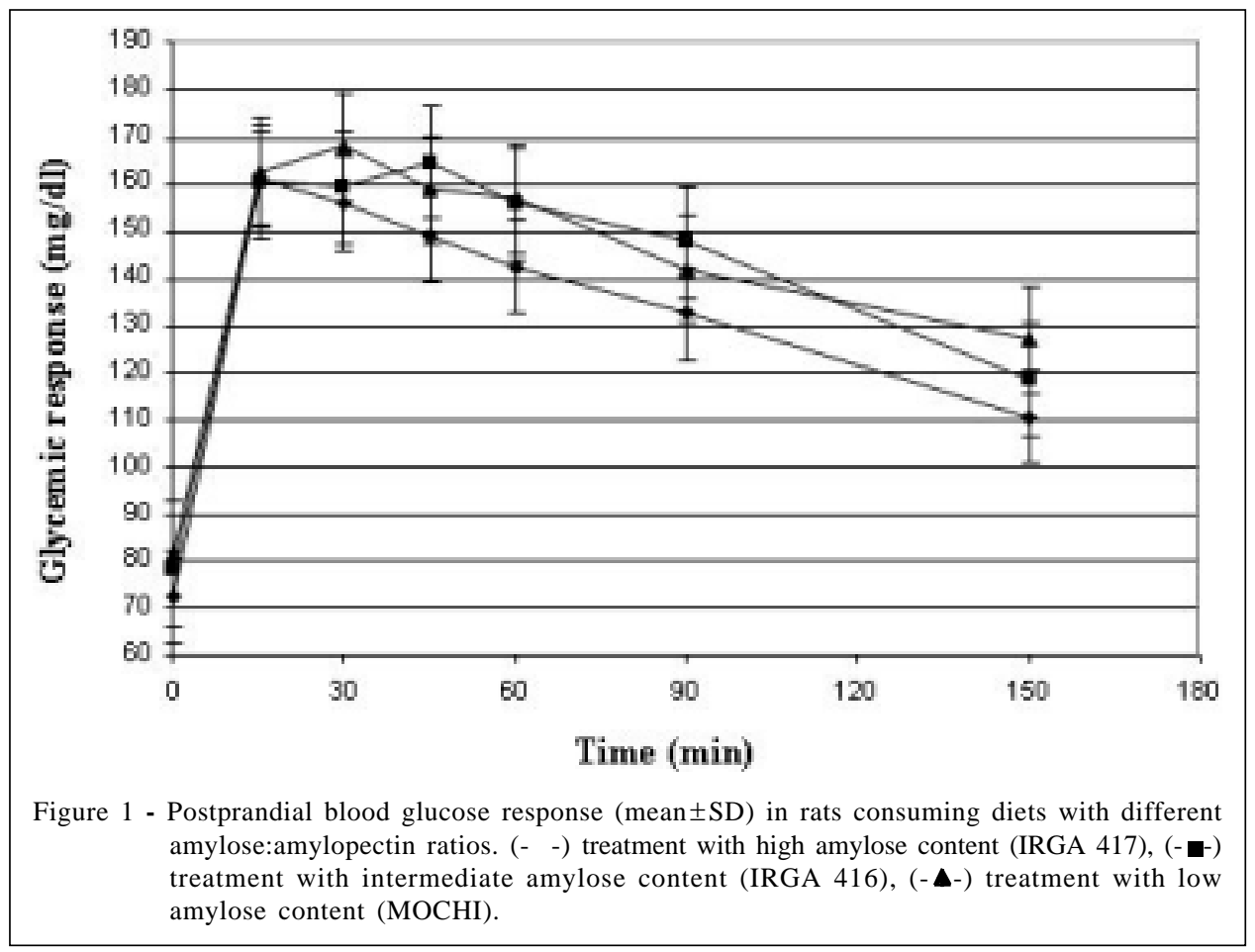

also observed that amylose content is directly related to glycemic and insulinemic responses.

The higher postprandial blood glucose response in the animals undergoing treatment with intermediate (IRGA 416) and low (MOCHI) amylose content is explained by the lower digestibility of this polymer when compared to amylopectin. Although not significant, the lower glycemic response in the treatments with high amylose content is especially important for patients with diabetes, helping in the maintenance of regular levels of blood glucose. According to JENKINS et al. (1987), high-carbohydrate diets, particularly in the form of high-glycemic index carbohydrates, are related to various deleterious effects like postprandial hyperinsulinemia, ß-cell dysfunction with subsequent development of insulin resistance, obesity, atherosclerosis, among other chronic diseases in the modern society.

Some researchers relate high blood glucose concentrations as being the main determining factor of high serum total cholesterol and triglyceride concentrations, influencing the progression of coronary diseases and non-insulin-dependent diabetes (ZAVARINI et al., 1989). In the present work, the serum cholesterol and triglyceride levels were higher in the treatments with higher glycemic response (IRGA 416 and MOCHI) and the serum HDL cholesterol was not affected by the diet (Table 1).
Similarly to what was observed in the present work, BEHALL et al. (1988), evaluating the effect of diets with 30 and $70 \%$ of amylose on humans, did not observe significant differences in serum HDL cholesterol and observed a significant decrease in serum triglycerides, insulin and total cholesterol levels after the consumption of a diet rich in amylose compared to a diet rich in amylopectin. It was observed in these researches that the use of a diet rich in amylose can be beneficial for people with intolerance to a diet with standard carbohydrate and for obese and diabetic patients with high plasma glucose and insulin levels and apparent insulin resistance. Similarly, JENKINS et al. (1987) and PAWLAK et al. (2004), evaluating the effect of diets with high and low glycemic index on humans and animals, respectively, concluded that diets with lower glycemic response decrease postprandial blood glucose, triglycerides and total cholesterol, and damage caused to the pancreatic islets.

This fact can also be explained by the relationship between starch digestibility and its effect on glucose hepatic metabolism. Reaching the liver, glucose originated from starch degradation follows three main pathways: a) transported to the blood, in order to maintain its concentration sufficiently high to supply energy to the brain and other tissues; b) converted into glycogen, stored in the liver and muscles; c) converted into fatty acids, transported by 
the triglycerides (LINDER, 1991). Amylopectin, being more easily degraded, provides a higher glucose flow to the liver when compared to amylose, within the same period of time. This higher flow produces excess of glucose in the liver, which will be metabolized into fatty acids, and transported by triglycerides and cholesterol to be stored in the adipose tissue, resulting in an increase in serum triglycerides and cholesterol.

However, it is important to point out that, as opposed to expected, the fasting serum glucose concentration of the animals undergoing treatment with intermediate (IRGA 416) and low (MOCHI) amylose content was lower compared to those in IRGA 417 treatment (Table 1). According to BENTON (2002), the frequent intake of diets containing large amounts of starch has been associated with hypoglycemic response several hours after the meal. This event, also known as reactive hypoglycemia or food-stimulated (postprandial) hypoglycemia, can be produced by the high levels of insulin released for a prolonged period after the meal, so that the levels of blood glucose drop to such an extent that cerebral activity is disrupted. Fasting hypoglycemia most frequently happens in diabetic patients who make use of insulin for the treatment of diabetes mellitus. However, a number of other disorders are also associated with hypoglycemia, like insulinoma, endocrine deficiencies, postprandial reactive hypoglycemia, and inherited metabolic disorders.

The different amylose content of the experimental diets also affected pancreas weight, which was higher in the treatments with intermediate (IRGA 416) and low (MOCHI) amylose contents. The liver weight was higher in the animals undergoing treatment with high (IRGA 417) amylose content (Table 1).

Several researches with animals have evaluated the effect of diets containing starches with different digestibility in the weight of organs such as liver and kidney (KABIR et al., 1998; KIM et al., 2003), however no researches evaluating the pancreas weight were found. Pancreas is the main organ responsible for producing, storing and secreting hormones and enzymes responsible for digestion and blood glucose levels (insulin and glucagon). So this increase in the weight of the pancreas of the animals undergoing treatment with intermediate (IRGA 416) and low (MOCHI) amylose content can be explained by the increase in metabolic activity in this organ, since amylopectin, being more quickly digested than amylose, can produce a sharper increase in the blood postprandial glucose levels, demanding a higher production of insulin by the pancreas to regulate these increased levels. Thus, this increased insulin requirement by the metabolism promotes a hypertrophy and/or hormone accumulation in this organ, which can explain the increased pancreas weight observed in the animals of the treatments containing intermediate and low amylose content (IRGA 416 and MOCHI). Moreover, PAWLAK and colleagues (2004), when studying the effect of diets with high and low glycemic responses on glycemic and lipidic metabolism in rats, observed that the pancreatic islets of the animals consuming a high glycemic response diet showed a significant increase in the proportion of abnormal ßcells, with severe disruption of islet-cell architecture and islet fibrosis, which could result in an increase in the organ's weight.

As for liver weight of the animals, no differences were observed in the organ's weight in response to diets with different digestibilities (KABIR et al., 1998; KIM et al., 2003), while others (ZHOU \& KAPLAN, 1997) observed that liver weight was significantly lower in the low digestibility diets, thought no effect of the amylose:amylopectin ratio was observed. In the present study, liver weight also did not correlate with the amylose:amylopectin ratio in rice grains, since the treatments with low (MOCHI) and high (IRGA 417) amylose content presented higher organ's weights.

\section{CONCLUSION}

The amylose:amylopectin ratio significantly affects rice starch digestion in the gastrointestinal tract. Thus, amylose content, normally used to evaluate some properties of product consumption, can aid in the choice of the grain to be used in the diet aiming at controlling some biologically relevant parameters, such as blood glucose and triglycerides concentrations.

\section{REFERENCES}

AOAC, Association of Official Analytical Chemists. Official Methods of Analysis of the AOAC International. 16.ed. Washington, DC, 1995. Supplement 1998.

BEHALL, K.M. et al. Effect of starch structure on glucose and insulin responses in adults. American Journal of Clinical Nutrition, v.47, p.428-432, 1988. Available from: <http:// www.ajcn.org/content/47/3/428.full.pdf+html $>$. Accessed: Oct 5, 2011.

BENTON, D. Carbohydrate ingestion, blood glucose and mood. Neuroscience \& Biobehavioral Reviews, v.26, p.293-308, 2002. Available from: <http://www.sciencedirect.com/science/ article/pii/S0149763402000040>. Accessed: Jan 17, 2008. doi: 10.1016/S0149-7634(02)00004-0.

BRAND-MILLER, J. et al. Rice: a high or low glycemic index food? American Journal of Clinical Nutrition, v.56, 
p.1034-1036, 1992. Available from: <http://www.ajcn.org/ content/56/6/1034.full.pdf+html>. Accessed: Jan 20, 2008.

BROUNS, F. et al. Resistant starch and "the butyrate revolution". Trends in Food Science and Technology, v.13, p.251-261, 2002. Available from: <http://www.sciencedirect.com/science/ article/pii/S0924224402001310>. Accessed: Jan 17, 2008. doi: 10.1016/S0924-2244(02)00131-0

CHERBUT, C. et al. Digestive and metabolic effect of potato and maize fibers in human subjects. British Journal of Nutrition, v.77, p.33-46, 1997. Available from: Comut Biblioteca Central UFSM. Accessed: Jan 10, 2008.

COFFMAN, W.R.; JULIANO, B.O. Nutritional quality of cereal grains: Genetic and agronomic improvement. In: OLSON, R.A.; FREY, K.J. Rice. Madison: American Society of Agronomy, 1987. p.101-131.

DEMIGNÉ, C.; RÉMÉSY, C. Influence of unrefined potato starch on cecal fermentations and volatile fatty acid absorption in rats. Journal of Nutrition, v.112, p.2227-2234, 1982. Available from: <http://jn.nutrition.org/content/112/12/ 2227.full.pdf+html>. Accessed: Jan 17, 2008.

EGGUM, B.O. et al. The resistant starch, undigestible energy and undigestible protein contents of raw and cooked milled rice. Journal of Cereal Science, v.18, p.159-170, 1993. Available from: <http://www.sciencedirect.com/science/article/ pii/S073352108371043X>. Accessed: Jan 18, 2008. doi: 10.1006/jcrs.1993.1043

FREI, M. et al. Studies on in vitro starch digestibility and the glycemic index of six different indigenous rice cultivars from the Philippines. Food Chemistry, v.83, p.395-402, 2003. Available from: <http://www.sciencedirect.com/science/article/ pii/S0308814603001018>. Accessed: Jan 20, 2008. doi: 10.1016/S0308-81 46(03)00101-8.

GILBERT, G.A.; SPRAGG, S.P. Iodine Sorption: "Blue Value”. In: WHISTLER, R.L. Methods in carbohydrate chemistry: volume IV - starch. London: Academic, 1964. p.168-169.

GODDARD, M.S. et al. The effect of amylose content on insulin and glucose responses to ingested rice. American Journal of Clinical Nutrition, v.39, p.388-392, 1984. Available from: <http://www.ajcn.org/content/39/3/ 388.full.pdf+html >. Accessed: Jan 20, 2008.

HU, P. et al. Starch digestibility and the estimated glycemic score of different types of rice differing in amylose contents. Journal of Cereal Science, v.40, p.231-237, 2004. Available from: <http://www.sciencedirect.com/science/article/pii/ S0733521004000669>. Accessed: Jan 17, 2008. doi: 10.1016/ j.jcs.2004.06.001.

JENKINS, D.J.A. et al. Metabolic effects of a low-glycemicindex diet. American Journal of Clinical Nutrition, v.46, p.968-975, 1987. Available from: <http://www.ajcn.org/content 46/6/968.full.pdf+html >. Accessed: Jan 17, 2008.

KABIR, M. et al. Dietary amylose-amylopectin starch content affects glucose and lipid metabolism in adipocytes of normal and diabetic rats. Journal of Nutrition, v.128, p.35-43, 1998. Available from: <http://jn.nutrition.org/content/128/1/ 35.full.pdf+html>. Accessed: Jan 20, 2008.

KIM, W.K. et al. Effect of resistant starch from corn and rice on glucose control, colonic events, and blood lipid concentration in streptozotocin-induced diabetic rats. Journal of Nutritional Biochemistry, v.14, p.166-172, 2003. Available from: <http:/ / w w w. sciencedirect. com/ s cience/article/pi i / S0955286302002814>. Accessed: Jan 18, 2008. doi: 10.1016/ S0955-2863(02)00281-4.

LINDER, M.C. Nutrition and metabolism of carbohydrates. In: __ Nutritional biochemistry and metabolism with clinical applications. 2.ed. United States of America: Appleton \& Lange, 1991. p.21-48.

PAWLAK, D.B. et al. Effects of dietary glycaemic index on adiposity, glucose homoeostasis, and plasma lipids in animals. Lancet, v.364, p.778-785, 2004. Available from: <http:// www.thelancet.com/journals/lancet/article/PIIS 0140 6736(04)16937-7/abstract>. Accessed: Jan 17, 2008. doi: 10.1016/S0140-6736(04)16937-7.

RAMIREZ, I. Starch flavor: apparent discrimination between amylopectin and amylose by rats. Physiology \& Behavior, v.50, n.6, p.1181-1186, 1991. Available from: <http:// w w w. sciencedirect . com/s cience/article / pi i/ 003193849190580H>. Accessed: Jan 18, 2008. doi: 10.1016/ 0031-9384(91)90580-H.

REEVES, P.G. et al. AIN-93 purified diets for laboratory rodents: final report of the American Institute of Nutrition ad hoc writing committee on the reformulation of the AIN-76A rodent diet. Journal of Nutrition, v.123, p.1939-1951, 1993. Available from: $<$ http://jn.nutrition.org/content/123/11/1939.full.pdf+html>. Accessed: Jan 20, 2008.

SCLAFANI, A. et al. Starch preference in rats. Neuroscience \& Biobehavioral Reviews, v.11, n.2, p.253-262, 1987. Available from: <http:/www.sciencedirect.com/science/article/ pii/S0149763487800337>. Accessed: Jan 20, 2008. doi: 10.1016/S0149-7634(87)80033-7.

YOUNES, H. et al. Resistant starch exerts a lowering effect on plasma urea by enhancing urea $\mathrm{N}$ transfer into the large intestine. Nutrition Research, v.15, p.1199-1210, 1995. Available from: <http://www.sciencedirect.com/science/article/pii/ 027153179500079X>. Accessed: Jan 18, 2008 . doi: 10.1016/ 0271-5317(95)00079-X.

ZAVARINI, I. et al. Risk factors for coronary artery disease in healthy persons with hyperinsulinaemia and normal glucose tolerance. New England Journal of Medicine, v.320, p.702706, 1989. Available from: <http://www.nejm.org/doi/pdf/ 10.1056/NEJM198903163201105>. Accessed: Jan 20, 2008. doi: 10.1056/NEJM198903163201105.

ZHOU, X.; KAPLAN, M.L. Soluble amylose cornstarch is more digestible than soluble amylopectin potato starch in rats. Journal of Nutrition, v.127, n.7, p.1349-1356, 1997. Available from: <http://jn.nutrition.org/content/127/7/ 1349.full.pdf+html>. Accessed: Jan 18, 2008. 